Review

\title{
Drivers and Constraints of Critical Materials Recycling: The Case of Indium
}

\author{
Jenni Ylä-Mella * and Eva Pongrácz
}

Energy and Environmental Engineering, Faculty of Technology, University of Oulu, 90014 Oulu, Finland; eva.pongracz@oulu.fi

* Correspondence: jenni.yla-mella@oulu.fi

Academic Editor: Benjamin C McLellan

Received: 5 September 2016; Accepted: 31 October 2016; Published: 2 November 2016

\begin{abstract}
Raw material criticality studies are receiving increasing attention because an increasing number of elements of great economic importance, performing essential functions face high supply risks. Scarcity of key materials is a potential barrier to large-scale deployment of sustainable energy and clean-tech technologies as resorting to several critical materials. As physical scarcity and geopolitical issues may present a barrier to the supply of critical metals, recycling is regarded as a possible solution to substitute primary resources for securing the long-term supply of critical metals. In this paper, the main drivers and constraints for critical materials recycling are analyzed from literature, considering indium as a case study of critical materials. This literature review shows that waste electrical and electronic equipment (WEEE) could be a future source of critical metals; however, the reduction of dissipation of critical materials should have much higher priority. It is put forward that more attention should be paid to sustainable management of critical materials, especially improved practices at the waste management stage. This calls for not only more efficient WEEE recycling technologies, but also revising priorities in recycling strategies.
\end{abstract}

Keywords: critical materials; indium; recycling; WEEE; open loop; dissipative loss

\section{Introduction}

Criticality is a research area receiving increasing attention. A raw material is labelled "critical" when the risks of supply shortage and their impacts on the economy are higher compared with most of the other raw materials [1]. Materials compiled in Table 1 are considered as critical within the EU in 2014 [2].

Table 1. Raw materials identified as critical within the EU in 2014 [2].

\begin{tabular}{ccccc}
\hline \multicolumn{4}{c}{ Raw Material } \\
\hline Antimony & Cobalt & Germanium & Natural graphite & Light REEs $^{2}$ \\
Beryllium & Coking Coal & Indium & Niobium & Heavy REEs ${ }^{2}$ \\
Borates & Fluorspar & Magnesite & PGMs ${ }^{1}$ & Silicon metal \\
Chromium & Gallium & Magnesium & Phosphate rock & Tungsten \\
\hline
\end{tabular}

${ }^{1}$ Platinum group metals; ${ }^{2}$ Rare Earth Elements.

Critical materials are present in a wide range of products across many sectors of the economy. In many cases they appear in relatively small quantities, but they frequently perform essential functions, often in high value goods or strategic technologies [3]. Many of these critical materials are essential components for information and communication technology (ICT) electronics as well as carbon-free energy technologies and clean-tech electronic devices. It is estimated that clean energy technologies 
constitute about $20 \%$ of global consumption of critical materials [4] and the share of global consumption of critical materials will grow as clean energy technologies are deployed more widely in the decades ahead $[5,6]$.

Geological scarcity is not the key issue for determining criticality of raw materials. The EU study on the criticality of materials concluded that global reserve figures are not reliable indicators of long term availability. Of greater relevance are changes in the geopolitical and economic framework that impact on the supply and demand of raw materials, such as growing demand for these critical raw materials in developing economies and for emerging technologies. For example, the US Department of Energy recognized that several clean energy technologies use materials at risk of supply disruptions in the short term [4]. Further, the EU's criticality study assessed that supply risks may arise within a time period of 10 years, which would give rise to unrealistic expectations regarding the possibility for policy makers to intervene [1].

Aim of the Study

Geological scarcity is not the key issue in determining of critical metals but their physical scarcity, concentration of production and geopolitical issues may present a barrier to their supply. Therefore, recycling is regarded as a possible solution to substitute primary resources for securing the long-term supply of critical metals. In this paper, a literature review has been conducted in order to analyze the main drivers and constraints for critical materials recycling, considering indium as a case study of critical materials.

\section{The Main Uses of Indium}

An amplifying factor for raw material criticality is its competing needs and uses. In the case of indium, there are only a few main applications consuming the major share of world production. Up to $75 \%$ of globally refined indium was used to produce indium tin oxide (ITO) in 2012 [7], used as a transparent conductive layer mainly in LCD and other flat panels, touch panels, and electroluminescent lamps [8].

Indium has an important role also in manufacturing thin film (TF) photovoltaic (PV) systems. PV systems are based on the use of semiconductors that generate electric power when exposed to sunlight. At present, two types of PV technologies are commonly available; crystalline silicon (c-Si) based (first generation) technologies and inorganic TF (second generation) technologies $[9,10]$. $\mathrm{TF}$ technologies, for one, include cadmium telluride (CdTe), copper indium gallium selenide (CIGS), and triple junction (GaAs, Ge, GaInP2) technologies. TF technologies were recently gained in increasing importance due to low production costs, low energy and materials demands, and potential for future cost reduction [8]. Currently, PV manufacturing accounts for less than $2 \%$ of total demand of indium [5].

Light emitting diodes (LEDs) rely on indium as well. LEDs are superior in energy efficiency, as they convert the input electric energy effectively into visible light. In addition to wide variety of lighting applications, indium based LEDs are also used in optical data transfer and LED displays or computer monitors in the cases where high image stability is required [8].

Other major applications for indium are alloys and solders. The addition of indium improves the strength, hardness, and corrosion resistance of alloys [11] and conduces a high resistance to fatigue and seizure [8]. Indium containing alloys are mainly used in ball bearings manufacturing but some of them are used also in electronics for fixing semiconductors chips to a base of printed circuit boards [8].

\section{Drivers for Indium Recycling}

\subsection{Emerging Global Demands}

Demand for ITO in the production of LCD screens has increased in recent years, and this trend is expected to continue in the foreseeable future. Growing demand is expected especially for smalland medium-sized LCD panels due to growing popularity of e-books, smartphones, and tablets, 
while growth rates for large-sized panels are estimated to be more moderate. Globally, growth in demand for LCDs is the strongest for TVs in developing economies, and for tablets and smartphones in developed countries [12]. In addition to increasing LCD production, new indium containing technologies were actively developed in the recent years-e.g., to replace amorphous silicon with indium-gallium-zinc-oxide (IGZO) [13,14] — to be applied in the variety of consumer electronics such as organic light-emitting diode (OLED) televisions, smartphones, and tablets [15].

In the energy sector, future energy strategies rely on the widespread deployment of carbon-free renewable energy technologies such as solar photovoltaics (PV). For instance, the Energy Roadmap for 2050 lays down ambitious decarbonization plans for Europe. By 2050, 80\%-95\% cutting of greenhouse gas emissions below 1990 levels is envisioned, which means that Europe's electricity sector will have to be almost carbon-free [16]. Currently, compared to demand, the production of electricity from PV is still on a very low level. Therefore, in order to contribute to a significant share of world electricity production, a massive growth in the PV industry is needed. Scenarios predict that PV technologies may provide up $25 \%$ of global electricity demand by 2050 [17]. Further, c-Si technologies are expected to lose their current dominating position while TF technologies will account for about $30 \%$ of the PV market by 2020 [9] and already $50 \%$ by 2030 [10]. However, their widespread distribution can be constrained by the criticality of tellurium, indium, and silver $[9,10,17]$.

\subsection{Limitations in Primary Production}

Most of the critical materials are not available on their own, but only as by-products of a few main industrial metals. In case of indium, almost all production occurs as by-product of zinc although indium can be associated also with tin, lead, copper, and iron ores. Concentrations of this kind of "companion metals" are typically so low in ores that their value are negligible or very small compared to main metals and, thus, they might not be recovered nor even be recognized in prices paid for concentrates [18]. This means that the primary production of critical materials is limited not only by the demand and supply of the major metals [17,19], but also whether they are recovered or not in refineries [20,21]. Low concentrations and by-production of critical metals have led the situation, where they are seldom reported as extractable commodities by the mining industry, which, for one, creates various uncertainties when estimating the global resources and unexploited reserves of critical metals [18].

In addition to limited volumes of the companion metals production, also geopolitical issues may present a barrier to supply. Because the world production of critical materials is typically concentrated strongly in a few countries, the risk of supply disruptions and volatility of prices are increased due to political and/or economic reasons. For example, China has been the main global supplier of primary indium over the years, originating as a by-product of zinc-sulfide ore processing $[12,15,22]$. Chinese indium consumption has increased rapidly and, thus, China has recently transitioned from primarily exporting indium to primarily consuming indium [23]. An increase domestic ITO production and growing demand in China have resulted in upward pressure on price [9]. However, the prices of indium suddenly dropped temporarily in 2015 due to absence of Chinese investors' demand coincident with the halting indium deliveries of certain exchange warehouses [22].

Global refining production of indium has been increased in the recent years, from around 780 tons in 2012 to 845 tons in 2014 [7,22]. However, the amount of annual world refinery production has dropped to the level of 755 tons in 2015 due to decreased prices [22], which effectively illustrates strong economic drivers behind increasing production of by-product metals. China is expected to continue to be the main global supplier of primary indium in the forthcoming years. However, Japan and the Republic of Korea are increasing their recycling capabilities from scrap generated in ITO production. Moreover, the prospect for indium supply from mine wastes has been found to be substantial [24], as indium-containing concentrates were typically treated in the past by smelters, which could not extract indium. These indium containing residues, such as tailings and slags, are now economical to 
treat because of improved recovery process technologies and higher indium prices [25]. Additionally, some new exploration projects are also in progress, mostly in Canada [26].

\subsection{Unique Technical Properties of Indium}

Considerable price volatility and various supply concerns associated with indium are potential barriers to large-scale deployment of technologies that rely on indium [5,9,27-29]. Therefore, there is intensive ongoing research to develop alternatives for indium and ITO. Few potential substitutes for indium are found in some applications-e.g., PEDOT [Poly(3,4,-ethylene dioxythiophene)] in flexible displays [30] and touch screens [31], as well as gallium in photovoltaic cells [32,33]. Moreover, antimony tin oxide (ATO) coatings have been developed and successfully fabricated for applying to flexible electronics [34,35]. According to the recent substitutability study of metals [36], the substitution potential of indium varies between its main applications; an adequate substitute-i.e., aluminium-doped zinc oxide-exists for ITO thin film coatings, while certain gallium based substitutes providing a good performance were determined for solders and alloys, as well as electrical components and semiconductors [36]. However, in many cases, substitution reduces the performance of technologies, shifts the problem to other critical raw materials, or is not economically viable [36,37].

Because there are no good substitutes for indium to be used in ITO thin-film coatings [36], research has focused on indium recycling from its main applications of LCD screens and photovoltaic modules in order to ensure long-term supply of indium. Based on the literature, several mechanical [38,39], thermal [40], and hydrometallurgical processes [41-43] as well as their combinations [44-46] have been researched. Some recycling technologies for PV modules to recover thin-film materials are even commercially available; however, several challenges related to process optimization and economics of recycling processes still exist [40]. For example some solvent-based stripping and selective extraction methods (e.g., [47]) require large quantities of potential dangerous solvents, leading to problem shifting, such evaporative losses, solvent wastes, and health hazards.

\section{Constraints of Indium}

\subsection{High Dissipative Losses}

Dissipative material losses cover point and diffuse emissions with no option for recovery [48]. The principal drivers for the dissipation are explicitly dissipative applications, minor concentrations in final products and ineffective collection and recycling systems. Dissipative losses may occur at every stage of the material's life cycle; however, the end-of life (EOL) stage is a noteworthy contributor. A screening of dissipative losses for critical materials has been performed by Zimmermann and Gößling-Reisemann [49]. They found that the majority of critical materials have dissipation rates of over $50 \%$. Dissipative losses into the environment appear as to be more severe than dissipation into the other material flows and landfills. Although the assumption is that dissipated metals into other material flows are theoretically still recoverable, that is not necessarily the case. Recovery from the receiving medium later may be technically or economically unfeasible. Technical and economic feasibility is, however, a dynamic feature; materials might be less dissipative in future due to progress of technical knowledge, market situation, and/or destination of the dissipated materials [49].

In the case of indium, the current dissipation rate of $90 \%$ is assumed, mainly to other material flows or landfills [49]. Ciacci et al. [50] argues that the dissipative use could be intended or unintended. Inherently dissipative use occurs in only a minor share of total flows for a few metals, whereas unintended dissipation is multifold common form of material use. Unintended dissipative use of materials could be "currently unrecyclable" or "potentially recyclable" [50]. In the case of indium, the major share of material stream in use is currently unrecyclable because recycling is not feasible due to technological and economical barriers, such as a lack of appropriate technology, loss of material quality, or low economic incentives compared to recycling costs. 
According to the global substance flow analysis (SFA) of indium carried out by Yoshimura et al. [51], dissipation of indium can be divided into three categories: dissipation in mining, smelting, and refining; losses during the recovery processes; and discarded EOL products. The SFA showed that, in 2004, the most considerable dissipation occurred in the production phase, mainly into mining tailings and smelter sludge due to low extraction efficiency of indium. Notwithstanding, there are notable losses also in manufacturing and EOL phases of indium containing products [51]. However, demand and production of indium has been multiplied since this SFA conducted in 2008; therefore, refining efficiency has notably improved in indium production over recent years. In the meanwhile, dissipation losses in recovery and EOL stages have increased. According to the more recent global SFA of indium conducted by Licht et al. [19], a process efficiency for indium was already $78 \%$ in 2011. They argue that, although there is still some improvement potential in the production phase, the greatest efforts should be required in increasing end-of-life (EOL) recycling in order to meet increasing indium demand in the future [19]. On the other hand, the prospect for indium supply from mine wastes has been found to be substantial [24]; therefore, the priority for indium-rich countries should be on better recovery at the mining stage [52]. For instance, notwithstanding of Australia's large indium-containing zinc reserves, indium refinery capacity in Australia is currently very limited and limits the exploitation potential [21].

\subsection{Open Cycles}

The other main challenge for critical materials recycling is open cycles. The life cycle of a metal is closed if EOL products are entering appropriate recycling chains, leading to recyclates replacing primary metals. Conversely, the life-cycle is open if EOL products are neither collected for recycling, nor entering those recycling streams that are capable of recycling the particular metal efficiency. Open cycles include products being discarded to landfills, products recycled through inappropriate technologies where metals are not or only inefficiently recovered and metals recycling in which the functionality of the EOL metal is lost. Non-functional recycling is that portion of EOL recycling in which the metal is collected as old metal scrap and incorporated in an associated large magnitude stream. This will lead to an open metal life cycle [53]. A major challenge is that open cycles are typical for many critical metals in consumer goods such as electronics and small appliances [54]. The reasons are [53]

- Product design that make disassembly and material separation difficult or impossible;

- High mobility of products and multiple changes of ownership;

- Low awareness levels about loss of resources;

- Missing economic recycling incentives;

- Lack of appropriate recycling infrastructure for EOL management of complex products in many developing or emerging economies;

- In industrial countries, many goods such as small electronics are "hibernating" in drawers and closets;

- Recycling technologies have not kept pace with complex and diverse modern products.

In the case of indium, open cycles are also one of the main challenges that have to be solved. Even though ITO in LCDs are a dominant application of indium, a wide variety of goods, versatile product design and extremely low concentrations in final products reduce recycling potential and hamper development of economically viable recycling processes. The recent trend of smaller and lighter LCD applications also hinders economic viability of recycling, because achieving sufficient volumes of EOL product for recycling turns even more difficult. In addition to economic issues, requirements of the extremely high purity of indium required in the ITO production set challenges for development of indium recycling processes. For example, a $99.999 \%$ purity of indium is required for ITO and TF PV module production, and recycling technologies currently in research are yet unable to reach this level [38]. 


\subsection{Present Recovery Practices and Policies}

Collection rates of WEEE have remained relatively low, despite efforts put into practice by authorities and companies across the world over the last 10 years. For instance, it is estimated that collected WEEE amounts in the EU are only around one-third of the amounts of EEE put on the market annually [55]. Shortcomings in awareness and economic incentives explain it partly; however, several studies show that the more inconvenient the recycling schemes are, the lower also the participation and recovery rates [56,57], which seems to be the case also in many WEEE recycling schemes [58-60].

It seems that current recycling schemes of collected WEEE are ineffective in capturing indium and other critical metals. Recycling failure occurs when metals are not captured through any of the recycling streams, as they are dissipated in use, or end up in landfills at the EOL stage, or when the metals are not recovered to final recycling fractions [53]. The reason for low recycling rates of critical materials is partially their low percentages in the devices [50] but the reasons can also be found in product design, low awareness levels, missing economic incentives for recycling, and lack of appropriate recycling technologies and infrastructure for EOL [61]. The current trend of product miniaturization and increased integration of materials complicates the future of metals recycling in the coming years [50]. Moreover, several current adverse practices, e.g., mixing of product parts of different compositions and using destructive and unselective technologies, are also commonly used in the collection and pre-treatment stages, which reduces the recycling yields and quality of recovered materials [62,63].

From the critical materials point of view, current recycling policies put too much focus on maximizing recycling rates; the goals of high recycling rates and high product qualities often contradict each other $[48,64]$. It is estimated that up to $90 \%$ of critical metals are dissipated after use, to other materials streams during recycling or to landfills [49]. An essential solution to reduce dissipation is increased recycling. In the case of indium, especially LCDs and PV installations can be a future secondary source [50]. However, recycling of WEEE has not caught up with the tremendous growth of ICT and other high-tech EEE in output volumes and complexity. The development of recycling technologies tends to experience a delay to product development and its need emerges only when the volumes of EOL devices expand noticeably. During this delay time, EEE design can develop to such complexity that recycling technologies have difficulty responding. As a case in point, the commercial recycling of LCDs is still in its infancy even though EOL LCDs are currently estimated to be the fastest growing waste stream in the EU [65]. Respectively, the recycling of TF PV is negligible at the moment. Although they have been around only since the late 1990s [66], their estimated lifetime is 20-30 years and, therefore, they are likely to appear in the waste phase ever more often [67].

\section{Discussion}

From a materials management point of view, the anthroposphere can be seen as a flow through reactor with a storage function. It has been put forward that there is a need to challenge the view that materials in the anthroposphere are intrinsically recoverable [68]. Materials leave the anthropogenic material cycle due to dissipative losses occurring and diminishing returns of secondary resources [48]. Substances from the stock-in-use are converted into unrecoverable forms and dissipated into the environment [69]. On a global scale, there is a continuous increase of material extraction from the earth's crust, resulting in large accumulations of materials particularly in urban areas. While the anthropogenic material stocks are growing, the amount of waste flows and emission rates increase with a certain delay.

To satisfy contemporary resource needs and to decrease environmental loadings, an obvious solution is to recycle as much as possible in order to substitute primary resources. The tendency indeed is that European legislation is setting out directives requiring increasing recycling rates. However, most recycling policies are aimed at quantitative goals in recycling percentages, rather than qualitative goals in terms of recovery of most valuable components. Kral et al. [48] criticized this 
view, claiming that the goals of high recycling rates and high product qualities often contradict each other. As well, they point out that this quantitative approach does not take into account the presence of unwanted substances ending up in the second generation products. Kral et al. [48] call for new priorities, to establish 'clean cycles'. While this is a valid aim, its main attention is ensuring the purity of major metal flows and views minor flows as "pollutants", weakening the quality of major flows.

Figure 1 illustrates a simplified metal product life cycle. It is indicated that all those substances that are not in clean cycles will end up either in the environment or in anthropogenic final sinks such as landfills. Final sinks also indicate "contaminated" recycling flows, which may contain minor components the current recycling system was unable to capture. While the 'clean cycle' view argues for the purity of major flows, an essential issue is also that valuable components, such as critical metals, may end up as "contaminants" in recycling streams, such as in the case of electronics [68]. The current view is, therefore, that of Figure 2a, where the minor metal is a "pollutant" in the major flow. For "contaminated" streams, the popular view might be that the minor element may still be recovered. This, however, may not be the case, as there may be techno-economic or even thermodynamic limitations [53]. In our view, in this case, the critical material in essence ends up in a final sink (Figure $2 b$ ), from where it is, practically, impossible to recover. Therefore, we suggest extending a view of "clean cycles" to include critical metals.

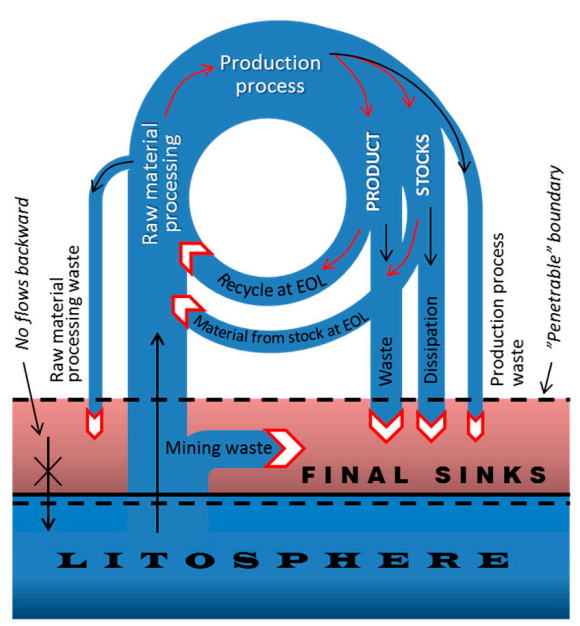

Figure 1. Simplified metal and product life cycle.

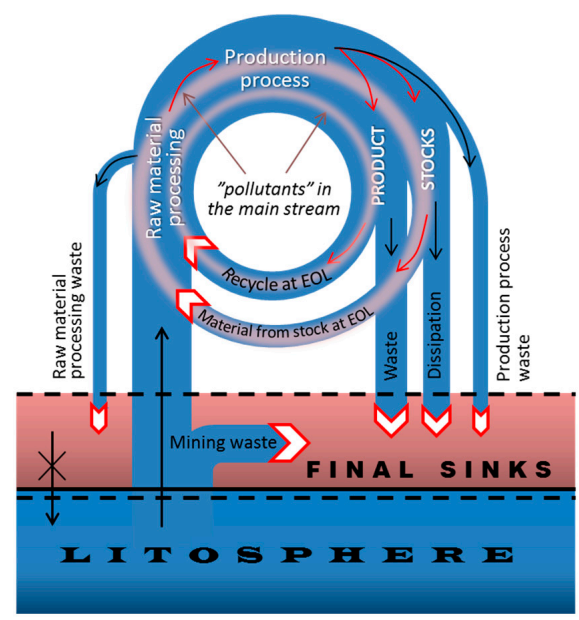

(a)

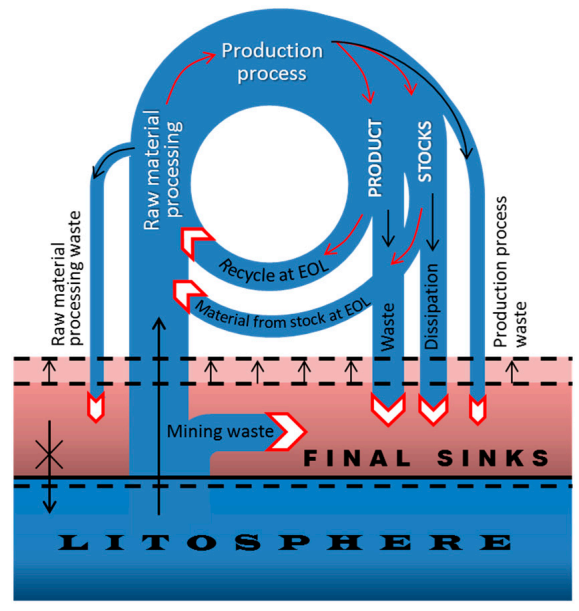

(b)

Figure 2. (a) Dissipation from the point of parent metal stream: the primary streams get contaminated; (b) From the point of the critical metal: the amount in finals grows. 
While the scientific community has been aware of the dangers of dissipative losses for some time, little guidance for reducing dissipative losses has been provided (e.g., [50]). In general, much more attention should be paid especially to the dissipative uses of critical materials, particularly those instrumental in carbon-free energy generation. It is argued here that strategic waste management considerations should be included in electronics and sustainable energy infrastructure design and future clean technology policies. In the case of building the future sustainable energy infrastructure, the material constraint may play a major role because of competing market forces, production bottlenecks, and reserve constraints. Production constraints may occur, because indium production is performed as a by-product of zinc exploration, sometimes associated also with copper or tin [20]. Moreover, increasing the output of the by-products is not only dependent on the production of "parent" metals under the given price schemes [17] but also on whether they are recovered rather than being discarded without having being processed [20].

Currently, the recycling rate of indium is under $1 \%$ and the main limitation to indium recycling is the high dissipation rate (90\%) [53]. A large percentage of indium dissipation is due to technological and economical barriers of recycling, such as lack of suitable technologies and economic incentives for recycling of very low concentrations [50,67], but also inefficient collection and recycling practices of waste electrical and electronic equipment WEEE currently exist [1]. On the other hand, more attention has recently been put on collection and recycling systems and, therefore, increased recovery rates of indium from end-of-life LCDs and photovoltaics could be expected in the future [50,67].

Electronic waste can be a future source of secondary indium; the secondary source with the most potential is thin films used in LCD and other flat panels (consume up to $80 \%$ of world production of indium), as well as PV panels and LEDs. However, it requires more considerations on materials' recyclability in the product design phase, more efficient collection of WEEE and improved recycling practices to minimize dissipative losses. For instance, improved sorting of valuable compounds and pre-processing with manual dismantling, as well as increased selective extraction could be worthy to implement in the future collection and recycling stages of WEEE. There are several research efforts on-going to improve the recovery of critical materials from EOL streams; however, most are limited either by recovery percentages, economics, the quality of the recovered materials, or all of the above. As well, some solvent-based methods, which are viable on a laboratory scale in fume cabinets, but when scaled up to industrial size, may lead to hazardous working conditions and problem shifting. In essence, we would end up solving one waste problem whilst creating another.

On the whole, more attention should be paid to sustainable management of indium and other critical materials. Although new reserves are being explored, by-product utilization processes are intensified [19,21] and secondary sources of critical metals are increasingly applied [24,52], it does not negate the need for re-thinking how the future infrastructure is built. Therefore, material recovery consideration should be fully embedded in design practices in order to reduce material losses and support the development of recovery possibilities at the EOL stage [50].

\section{Conclusions}

This paper reviews the main drivers and constraints for critical materials recycling presented in the literature, considering indium as an example of critical materials. Extensive research has already been conducted related to critical materials-e.g., global resources, current material flows, future supply options, as well as substitution potentials. The evidence suggests that there are several different aspects to approaching material criticality and finding an applicable solution to fulfill future material needs.

Constraints of critical materials may play a major role because of competing market forces, production bottlenecks, and reserve limitations; therefore, recycling is regarded as part of the solution to secure the long-term supply of critical materials. However, the view that critical materials in stock are intrinsically recoverable need to be revised. The issue of critical material recovery from stock cannot be approached from the end of life. In order to ensure that waste electrical and electronic equipment 
(WEEE) could be a future source of critical metals, the reduction of dissipation of critical materials should have much higher priority. More attention should be given to sustainable management of critical materials, especially improved practices at the production and waste management stages. This calls for not only more efficient WEEE recycling technologies, but also revising priorities in recycling strategies. As well, material recovery considerations should also be fully embedded in design and manufacturing practices. Ultimately, future infrastructure renovation strategies, such as constructing a low-carbon economy, need to be done with EOL considerations in mind, in order to ensure clean cycles of critical materials within the anthroposphere.

Acknowledgments: Financial support of the Kone Foundation is gratefully acknowledged.

Author Contributions: Jenni Ylä-Mella and Eva Pongrácz conceived together the content of the publication; Eva Pongrácz designed illustrations of metal and product life cycle; Jenni Ylä-Mella wrote the paper.

Conflicts of Interest: The authors declare no conflict of interest.

\section{References}

1. European Commission. Critical Raw Materials for the EU: Report of the Ad-Hoc Working Group on Defining Critical Raw Materials; European Commission: Brussels, Belgium, 2010. Available online: https:/ /ec.europa. eu/growth/tools-databases/eip-raw-materials/en/system/files/ged/79\%20report-b_en.pdf (accessed on 25 August 2016).

2. European Commission. Report on Critical Raw Materials for the EU: Report of the Ad-Hoc Working Group on Defining Raw Materials; European Commission: Brussels, Belgium, 2014. Available online: http://ec. europa.eu/DocsRoom/documents/10010/attachments/1/translations/en/renditions/pdf (accessed on 25 August 2016).

3. Department for Environment, Food and Rural Affairs (DEFRA). Resource Security Action Plan. Making the Most of Valuable Materials; Department for Environment, Food and Rural Affairs: London, UK, 2012. Available online: https:/ / www.gov.uk/government/publications/resource-security-action-plan-makingthe-most-of-valuable-materials (accessed on 25 August 2016).

4. U.S. Department of Energy (DoE). Critical Materials Strategy; U.S. Department of Energy: Washington, DC, USA, 2011. Available online: http://energy.gov/epsa/initiatives/department-energy-s-critical-materialsstrategy (accessed on 25 August 2016).

5. Bleiwas, D.I. Byproduct Mineral Commodities Used for the Production of Photovoltaic Cells; Circular 1365; U.S. Geological Survey: Reston, VA, USA, 2010. Available online: http://pubs.usgs.gov/circ/1365/ (accessed on 30 August 2016).

6. Fthenakis, V. Sustainability of photovoltaics: The case for thin-film solar cells. Renew. Sustain. Energy Rev. 2009, 13, 2746-2750. [CrossRef]

7. Chancerel, P.; Rotter, V.S.; Ueberschaar, M.; Marwede, M.; Nissen, N.F.; Lang, K. Data availability and the need for research to localize, quantify and recycle critical metals in information technology, telecommunication and consumer equipment. Waste Manag. Res. 2013, 31, 3-16. [CrossRef] [PubMed]

8. Peiró, L.T.; Méndez, G.V.; Ayres, R.U. Material flow analysis of scarce metals: Sources, functions, end-uses and aspects for future supply. Environ. Sci. Technol. 2013, 47, 2939-2947. [CrossRef] [PubMed]

9. Candelise, C.; Speirs, J.F.; Gross, R.J.K. Materials availability for thin film (TF) PV technologies development: A real concern? Renew. Sustain. Energy Rev. 2011, 15, 4972-4981. [CrossRef]

10. Elshkaki, A.; Graedel, T.E. Dynamic analysis of the global metals flows and stocks in electricity generation technologies. J. Clean. Prod. 2013, 59, 260-273. [CrossRef]

11. Alfantazi, A.M.; Moskalyk, R.R. Processing of indium: A review. Miner. Eng. 2003, 16, 687-694. [CrossRef]

12. U.S. Geological Survey (USGS). Mineral Commodity Summaries, Indium 2015; U.S. Geological Survey: Reston, VA, USA, 2015. Available online: http://minerals.usgs.gov/minerals/pubs/commodity/indium/mcs-2015indiu.pdf (accessed on 30 August 2016).

13. Kim, Y.C.; Lee, S.J.; Oh, I.-K.; Seo, S.; Kim, H.; Myoung, J.-M. Bending stability of flexible amorphous IGZO thin film transistors with transparent IZO/Ag/IZO oxide-metal-oxide electrodes. J. Alloys Compd. 2016, 688, 1108-1114. [CrossRef] 
14. Furuta, M.; Jiang, J.; Hung, M.P.; Toda, T.; Wang, D.; Tatsuoka, G. Suppression of negative gate bias and illumination stress degradation by fluorine-passivated In-Ga-Zn-O thin-film transistors. ECS J. Solid State Sci. Technol. 2016, 5, Q88-Q91. [CrossRef]

15. U.S. Geological Survey (USGS). Mineral Commodity Summaries, Indium 2014; U.S. Geological Survey: Reston, VA, USA, 2014. Available online: http://minerals.usgs.gov/minerals/pubs/commodity/indium/mcs-2014indiu.pdf (accessed on 30 August 2016).

16. European Commission. Energy Roadmap 2050 [COM(2011) 885]; European Commission: Brussels, Belgium, 2011. Available online: https://ec.europa.eu/energy/en/topics/energy-strategy/2050-energy-strategy (accessed on 30 August 2016).

17. Zuser, A.; Rechberger, H. Considerations of resource availability in technology development strategies: The case study of photovoltaics. Resour. Conserv. Recycl. 2011, 56, 56-65. [CrossRef]

18. Mudd, G.M.; Jowitt, S.M.; Werner, T.T. The world's by-product and critical metal resources part I: Uncertainties, current, reporting practices, implications and grounds for optimism. Ore Geol. Rev. 2016, in press. [CrossRef]

19. Licht, C.; Peiró, L.T.; Villabla, G. Global substance flow analysis of gallium, germanium, and indium. J. Ind. Ecol. 2015, 19, 890-902. [CrossRef]

20. Nassar, N.T.; Graedel, T.E.; Harper, E.M. By-product metals are technologically essential but have problematic supply. Sci. Adv. 2015, 1. [CrossRef] [PubMed]

21. Ciacci, L.; Nuss, P.; Reck, B.K.; Werner, T.T.; Graedel, T.E. Metal criticality determination for Australia, The US, and the planet-Comparing 2008 and 2012 results. Resources 2016, 5. [CrossRef]

22. U.S. Geological Survey (USGS). Mineral Commodity Summaries, Indium 2016; U.S. Geological Survey: Reston, VA, USA, 2016. Available online: http://minerals.usgs.gov/minerals/pubs/commodity/indium/mcs-2016indiu.pdf (accessed on 30 August 2016).

23. Duan, H.; Wang, J.; Liu, L.; Huang, Q.; Li, J. Rethinking China's strategic mineral policy on indium: Implication for the flat screens and photovoltaic industries. Prog. Photovolt. Res. Appl. 2016, 24, 83-93. [CrossRef]

24. Werner, T.T.; Mudd, G.M.; Jowitt, S.M. Indium: Key issues in assessing mineral resources and long-term supply from recycling. Appl. Earth Sci. 2015, 124, 213-226. [CrossRef]

25. Phipps, G.; Mikolajczak, C.; Guckes, T. Indium and Gallium: long-term supply. Renew. Energy Focus 2008, 9 , 56, 58-59. [CrossRef]

26. U.S. Geological Survey (USGS). Minerals Yearbook 2013, Indium; U.S. Geological Survey: Reston, VA, USA, 2015. Available online: http://minerals.usgs.gov/minerals/pubs/commodity/indium/myb1-2013-indiu. pdf (accessed on 30 August 2016).

27. Ayres, R.U. On the practical limits to substitution. Ecol. Econ. 2007, 61, 115-128. [CrossRef]

28. Fthenakis, V. Sustainability metrics for extending thin-film photovoltaics to terawatt levels. Mater. Res. Soc. Bull. 2012, 37, 1-6. [CrossRef]

29. Choi, C.H.; Cao, J.; Zhao, F. System dynamics modeling of indium material flows under wide deployment of clean energy technologies. Resour. Conserv. Recycl. 2016, 114, 59-71. [CrossRef]

30. Schaubroeck, D.; De Smet, J.; Willems, W.; Cools, P.; De Geyter, N.; Morent, R.; De Smet, H.; Van Steenbeerge, G. Surface analysis of the selective excimer laser patterning of a thin PEDOT:PSS film on flexible polymer films. Appl. Surf. Sci. 2016, 376, 151-160. [CrossRef]

31. Aleksandrova, M.; Videkov, V.; Ivanova, R.; Singh, A.K.; Thool, G.S. Highly flexible, conductive and transparent PEDOT:PSS/Au/PEDOT:PSS multilayer electrode for optoelectronic devices. Mater. Lett. 2016, 174, 204-208. [CrossRef]

32. Tiwari, B.; Hossain, M.J.; Bhattacharya, I. GaP/InGaAs/InGaSb triple junction current matched photovoltaic cell with optimized thickness and quantum efficiency. Sol. Energy 2016, 135, 618-624. [CrossRef]

33. Hwang, S.-T.; Kim, S.; Cheun, H.; Lee, H.; Lee, B.; Hwang, T.; Lee, S.; Yoon, W.; Lee, H.-M.; Park, B. Bandgap grading and $\mathrm{Al}_{0.3} \mathrm{Ga}_{0.7} \mathrm{As}$ heterojunction emitter for highly efficient GaAs-based solar cells. Sol. Energy Mater. Sol. Cells 2016, 155, 264-272. [CrossRef]

34. Kong, Z.; Li, Y.; Lu, X.; Zhu, Y.; Jiang, L. Fabrication and characterization of flexible, transparent and self-standing $\mathrm{Sb}$ doped $\mathrm{SnO}_{2}$ electrospun nanofiber films. Chem. J. Chin. Univ. 2015, 36, 55-60.

35. Hu, P.; Wu, G.; Zhang, Q.; Wang, H.; Li, Y. An antimony-doped tin oxide conductive network for flexible electronics based on electrospinning. J. Nanosci. Nanotechnol. 2016, 16, 5662-5667. [CrossRef] [PubMed] 
36. Graedel, T.E.; Harper, E.M.; Nassar, N.T.; Reck, B.K. On the materials basis of modern society. Proc. Natl. Acad. Sci. USA 2015, 112, 6295-6300. [CrossRef] [PubMed]

37. Wäger, P.A.; Lang, D.J.; Wittmer, D.; Bleischwitz, R.; Hagelüken, C. Towards a more sustainable use of scarce metals. A review of intervention options along the metals life cycle. GAIA Ecol. Perspect. Sci. Soc. 2012, 21, 300-309.

38. Berger, W.; Simon, F.; Weimann, K.; Alsema, E.A. A novel approach for the recycling of thin film photovoltaic modules. Resour. Conserv. Recycl. 2010, 54, 711-718. [CrossRef]

39. Giacchetta, G.; Leporini, M.; Marchetti, B. Evaluation of the environmental benefits of new high value process for the management of the end of life of thin film photovoltaic modules. J. Clean. Prod. 2013, 51, 214-224. [CrossRef]

40. Marwede, M.; Berger, W.; Schlummer, M.; Mäurer, A.; Reller, A. Recycling paths for thin-film chalcogenide photovoltaic waste-Current feasible processes. Renew. Energy 2013, 55, 220-229. [CrossRef]

41. Li, Y.; Liu, Z.; Li, Q.; Liu, Z.; Zeng, L. Recovery of indium from used indium-tin oxide (ITO) targets. Hydrometallurgy 2011, 105, 207-212. [CrossRef]

42. Virolainen, S.; Ibana, D.; Paatero, E. Recovery of indium from indium tin oxide by solvent extraction. Hydrometallurgy 2011, 107, 56-61. [CrossRef]

43. Swain, B.; Mishra, C.; Hong, H.S.; Cho, S.-S. Beneficiation and recovery of indium from liquid-crystal-display glass by hydrometallurgy. Waste Manag. 2016, 57, 207-214. [CrossRef] [PubMed]

44. Hasegawa, H.; Rahman, I.M.M.; Egawa, Y.; Sawai, H.; Begum, Z.A.; Maki, T.; Mizutani, S. Recovery of indium from end-of-life liquid-crystal display panels using aminopolycarboxylate chelants with the aid of mechanochemical treatment. Microchem. J. 2013, 106, 289-294. [CrossRef]

45. Rocchetti, L.; Beolchini, F. Recovery of valuable materials from end-of-life thin-film photovoltaic panels: Environmental impact assessment of different management options. J. Clean. Prod. 2015, 89, 59-64. [CrossRef]

46. Silveira, A.V.M.; Fuchs, M.S.; Pinheiro, D.K.; Tanabe, E.H.; Bertuol, D.A. Recovery of indium from LCD screens of discarded cell phones. Waste Manag. 2015, 45, 334-342. [CrossRef] [PubMed]

47. Ruan, J.; Guo, Y.; Qiao, Q. Recovery of indium from scrap TFT-LCDs by solvent extraction. Procedia Environ. Sci. 2012, 16, 545-551. [CrossRef]

48. Kral, U.; Kellner, K.; Brunner, P.H. Sustainable resource use requires "clean cycles" and safe "final sinks". Sci. Total Environ. 2013, 461-462, 819-822. [CrossRef] [PubMed]

49. Zimmermann, T.; Gößling-Reisemann, S. Critical materials and dissipative losses: A screening study. Sci. Total Environ. 2013, 461-462, 774-780. [CrossRef] [PubMed]

50. Ciacci, L.; Reck, B.K.; Nassar, N.T.; Graedel, T.E. Lost by design. Environ. Sci. Technol. 2015, 49, $9443-9451$. [CrossRef] [PubMed]

51. Yoshimura, A.; Daigo, I.; Matsuno, Y. Global substance flow analysis of indium. Mater. Trans. 2013, 54, 102-109. [CrossRef]

52. McLellan, B.C.; Yamasue, E.; Tezuka, T.; Corder, G.; Golev, A.; Giurco, D. Critical minerals and energy-Impacts and limitations of moving to unconventional resources. Resources 2016, 5. [CrossRef]

53. United Nations Environment Programme (UNEP). Recycling Rates of Metals—A Status Report; A Report of the Working Group on the Global Metals Flows to the International Resource Panel; United Nations Environment Programme (UNEP): Nairobi, Kenya, 2011. Available online: http://www.unep.org/ resourcepanel/Publications/AreasofAssessment/Metals/InternationalResourcePanelWorkonGlobalMetal/ tabid/132990/Default.aspx (accessed on 2 September 2016).

54. Hagelüken, C. The challenge of open cycles-Barriers to a closed loop economy demonstrated for consumer electronics and cars. In Proceedings of the R'07 World Congress-Recovery of Materials and Energy for Resource Efficiency, Davos, Switzerland, 3-5 September 2007; Hilty, L.M., Edelmann, X., Ruf, A., Eds.; Empa Materials Science and Technology: St. Gallen, Switzerland, 2007.

55. Eurostat. Waste Statistics—Electrical and Electronic Equipment. 2016. Available online: http://ec.europa.eu/ eurostat/statistics-explained/index.php/Waste_statistics_-_electrical_and_electronic_equipment (accessed on 2 September 2016).

56. Barr, S.; Gilg, A.W.; Ford, N.J. A conceptual framework for understanding and analysing attitudes towards household-waste management. Environ. Plan. A 2001, 33, 2025-2048. [CrossRef]

57. Wagner, T.P. Examining the concept of convenient collection: An application to extended producer responsibility and product stewardship frameworks. Waste Manag. 2013, 33, 499-507. [CrossRef] [PubMed] 
58. Saphores, J.M.; Ogunseitan, O.A.; Shapiro, A.A. Willingness to engage in a pro-environmental behavior: An analysis of e-waste recycling based on a national survey of U.S. households. Resour. Conserv. Recycl. 2012, 60, 49-63. [CrossRef]

59. Wang, Z.; Zhang, B.; Yin, J.; Zhang, X. Willingness and behavior towards e-waste recycling for residents in Beijing city, China. J. Clean. Prod. 2011, 19, 977-984. [CrossRef]

60. Yin, J.; Gao, Y.; Xu, H. Survey and analysis of consumers' behaviour of waste mobile phone recycling in China. J. Clean. Prod. 2014, 65, 517-525. [CrossRef]

61. United Nations Environment Programme (UNEP). Environmental Risks and Challenges of Anthropogenic Metal Flows and Cycles; A report of the Working Group on the Global Metals Flows to the International Resource Panel; United Nations Environment Programme (UNEP): Nairobi, Kenya, 2013. Available online: http://www.unep.org/resourcepanel/Publications/AreasofAssessment/Metals/ InternationalResourcePanelWorkonGlobalMetal/tabid/132990/Default.aspx (accessed on 2 September 2016).

62. Ardente, F.; Mathieux, F.; Recchioni, M. Recycling of electronic displays: Analysis of pre-processing and potential ecodesign improvements. Resour. Conserv. Recycl. 2014, 92, 158-171. [CrossRef]

63. Chancerel, P. Substance Flow Analysis of the Recycling of Small Waste Electrical and Electronic Equipment-An Assessment of the Recovery of Gold and Palladium. Ph.D. Thesis, Technical University of Berlin, Berlin, Germany, 4 December 2009.

64. Velis, C.A.; Brunner, P.H. Recycling and resource efficiency: It is time for a change from quantity to quality. Waste Manag. Res. 2013, 31, 539-540. [CrossRef] [PubMed]

65. Dodson, J.R.; Hunt, A.J.; Parker, H.L.; Yang, Y.; Clark, J.H. Elemental sustainability: Towards the total recovery of scarce metals. Chem. Eng. Process. Process Intensif. 2012, 51, 69-78. [CrossRef]

66. Birkmire, R.W.; McCandless, B.E. CdTe thin film technology: Leading thin film PV into the future. Curr. Opin. Solid State Mater. Sci. 2010, 14, 139-142. [CrossRef]

67. Zimmermann, T.; Gößling-Reisemann, S. Recycling potentials of critical metals-Analyzing secondary flows from selected applications. Resources 2014, 3, 291-318. [CrossRef]

68. Pongrácz, E. Critical minerals: Recycling vs. dissipative losses-The case of indium. In Proceedings of the 2014 Second Symposium on Urban Mining, Bergamo, Italy, 19-21 May 2014; Cossu, R., Ed.; CISA Publisher: Padova, Italy, 2014.

69. Ayres, R.U.; Ayres, L.W.; Råde, I. The Life Cycle of Copper, Its Co-Products and By-Products; International Institute for Environment and Development: London, UK, 2002. Available online: http://pubs.iied.org/ pdfs/G00740.pdf (accessed on 2 September 2016).

(C) 2016 by the authors; licensee MDPI, Basel, Switzerland. This article is an open access article distributed under the terms and conditions of the Creative Commons Attribution (CC-BY) license (http:/ / creativecommons.org/licenses/by/4.0/). 